\title{
In vitro antimicrobial activity and alternative control of anthracnose in papaya*
}

\section{Atividade antimicrobiana in vitro e controle alternativo da antracnose em mamão}

\author{
Héber Ferreira dos Reis ${ }^{1 * *}$ (D), Lilian Maria Arruda Bacchi ${ }^{1}$, \\ Silvana de Paula Quintão Scalon', Jasna Karoliny Pereira Flores ${ }^{1}$
}

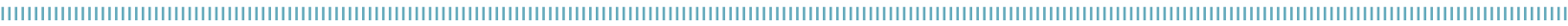

\begin{abstract}
We evaluated the efficacy of natural products in the control of papaya anthracnose, in vitro and in vivo. The in vitro experiments for evaluation of mycelial growth used a completely randomized $10 \times 4$ factorial design (treatments $\times$ evaluation periods) with eight replicates, with sporulation evaluated at the end of the experiment. The treatments involved the use of aqueous extract at concentrations of 5 and $15 \%$ for Syzygium aromaticum (L.) Merr. \& Perry (clove), Cinnamomum zeylanicum Breym (cinnamon), and Zingiber officinalis Rox. (ginger); 1 and 3\% chitosan; the fungicide Prochloraz at $100 \mu \mathrm{g} \cdot \mathrm{mL}^{-1}$; and a control (no treatment). For evaluating conidia germination, we used six treatments with five replicates. The treatments included $7.5 \%$ of each extract (clove, cinnamon, and ginger), $1.5 \%$ chitosan, and $50 \mu \mathrm{g} . \mathrm{mL}^{-1}$ of Prochloraz. For the in vivo experiment, "Formosa" papaya "Tainung 1" was used in a completely randomized design, with six treatments and four replicates to evaluate the severity of anthracnose caused by Colletotrichum gloeosporioides. The fruits were treated by immersion for $5 \mathrm{~min}$ with $15 \%$ clove, cinnamon, and ginger extracts, $8 \%$ chitosan, and control with distilled water, and immersion for $2 \mathrm{~min}$ in Prochloraz (33.75 g a.i./100 L). The treatments with 15\% clove extract and $8 \%$ chitosan were effective in all evaluations, resulting in a viable alternative to the fungicide Prochloraz. The treatments with ginger extract were less effective and those with cinnamon offered intermediate control.
\end{abstract}

KEYWORDS: Carica papaya; post-harvest diseases; plant extracts; chitosan.
RESUMO: Este trabalho teve por objetivo avaliar, in vitro e in vivo, a eficácia de produtos naturais no controle da antracnose do mamão. Os experimentos in vitro foram instalados em delineamento inteiramente casualizado, sendo para a avaliação de crescimento micelial considerado o esquema fatorial $10 \times 4$ (tratamentos $\mathrm{x}$ períodos de avaliação) com oito repetições, com a esporulação avaliada ao final do experimento. Os tratamentos utilizados foram: extrato aquoso nas concentraçôes de 5 e 15\% de Syzygium aromaticum (L.) Merr. \& Perry (cravo-da-índia), Cinnamomum zeylanicum Breym (canela) e Zingiber officinalis Rox (gengibre), quitosana 1 e 3\%, fungicida Procloraz a $100 \mu \mathrm{g} \cdot \mathrm{mL}^{-1}$ e testemunha (sem tratamento). Para a avaliação da germinação de conídios, foram considerados seis tratamentos com cinco repetiçóes. Foram utilizados os mesmos tratamentos, porém, nas concentraçôes de 7,5\% de cada extrato (cravo-da-índia, canela e gengibre), $1,5 \%$ de quitosana, e $50 \mu \mathrm{g} \cdot \mathrm{mL}^{-1}$ de Procloraz. Para o experimento in vivo, foram utilizados mamóes "Formosa" "Tainung 1", em delineamento inteiramente casualizado, sendo seis tratamentos com quatro repetiçóes para avaliaçáo de severidade de antracnose causada por Colletotrichum gloeosporioides. Os frutos foram tratados por imersão durante 5 minutos com extratos de cravo-da-índia, canela e gengibre a $15 \%$, quitosana a $8 \%$ e testemunha com água destilada, e imersão por 2 minutos em fungicida Procloraz (33,75 g i.a./100 L). Os tratamentos com extrato de cravo-da-índia a $15 \%$ e quitosana a $8 \%$ foram eficazes em todas as avaliaçôes, sendo uma alternativa viável ao fungicida Procloraz. Os tratamentos com extrato de gengibre foram menos eficientes, com controle intermediário para o extrato de canela.

PALAVRAS-CHAVE: Carica papaya; doenças pós-colheita; extratos vegetais; quitosana.

'Universidade Federal da Grande Dourados - Dourados (MS), Brazil

* This article is part of the doctoral thesis of the first author.

**Corresponding author: heber.f.reis@gmail.com

Received on: 02/20/2018. Accepted on: 08/01/2018

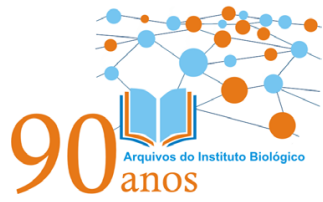




\section{INTRODUCTION}

Anthracnose of papaya, caused by Colletotrichum gloeosporioides Penz., is very important economically the fruits affected by this disease become unsuitable for commercialization and consumption. Although the fruits do not show symptoms of the disease at harvest, it manifests itself during the packaging, transportation, ripening, and commercialization phases, causing substantial losses (SIQUEIRA JUNIOR et al., 2011).

Post-harvest disease control in papaya is usually done by immersing the fruits in water at $48-49^{\circ} \mathrm{C}$ for $20 \mathrm{~min}$, followed by another immersion at $14^{\circ} \mathrm{C}$ for $20 \mathrm{~min}$. Subsequently, the application of waxes and fungicides is recommended to guarantee longer fruit survival (CARNELOSSI et al., 2009). In addition, the use of refrigeration or controlled atmosphere is fundamental to enhance control efficacy (CIA et al., 2010).

Although the use of fungicides is an important control strategy, their residues in fruits have generated cause for concern owing to their negative effects on human health and the environment. For example, in 2016, ANVISA prohibited the use of the active ingredient Prochloraz in pesticides, based on the results of its toxicological reassessment per the newly adopted guidelines and toxicological evaluation requirements (ANVISA, 2016).

As an alternative to fungicides, and for the post-harvest conservation of several fruits, the use of biofilms such as chitosan (a natural, edible polysaccharide extracted from the exoskeleton of crustaceans) has been investigated. It can form a semipermeable coating, prolonging post-harvest life by minimizing respiration rate and reducing fruit water loss (HERNÁNDEZ et al., 2011). Chitosan also has antifungal and antibacterial activity, showing in vitro its potential for inhibition of mycelial growth, as obtained for Rhizopus stolonifer (CIA et al., 2010).

Research with plant extracts or essential oils, obtained from medicinal plants of native Brazilian flora, such as clove (LUCAS, 2012; FONTANA et al., 2017), ginger (BRITO; NASCIMENTO, 2015; DIEMER, 2016), and cinnamon (ANDRADE; VIEIRA, 2016; BONILLA; SOBRAL, 2017), has indicated their potential to control phytopathogens. Essential oils not only exhibit a direct fungitoxic action, inhibiting mycelial growth and spore germination, but also affect the induction of phytoalexins, indicating the presence of compounds with elicitor characteristics (SCHWANESTRADA, 2009).

The objective of this study was to evaluate, in vitro and in vivo, the control of C. gloeosporioides, a causal agent of papaya anthracnose in the post-harvest period, using chitosan and extracts of cloves, cinnamon, and ginger.

\section{MATERIAL AND METHODS}

\section{Research site}

The in vitro experiments were conducted at the Laboratory of Agricultural Microbiology and Phytopathology of the Federal University of Grande Dourados (UFGD), Dourados, Mato Grosso do Sul, from September to December 2013.

\section{Mycelial sensitivity and sporulation of $C$. gloeosporioides in response to natural products and a fungicide}

The fungus C. gloeosporioides was isolated from disease lesions in "Formosa" papaya fruits and cultivated in potato-dextrose-agar (PDA) medium for six days at $25^{\circ} \mathrm{C}$, with a $12 \mathrm{~h}$ photoperiod. After fungal colony growth, consecutive repetitions were made until pure cultures were obtained. The confirmation of fungus identification was based on its morphological characteristics, per TARNOWSKI (2009) and TORRESCALZADA et al. (2012), through slide preparation and microscopic observations.

We used a completely randomized design, with ten treatments and eight replications. For evaluation of mycelial growth, we implemented a $10 \times 4$ factorial scheme, with ten treatments and four incubation periods $(2,4,6$, and 8 days). The treatments were aqueous extract at concentrations of 5 and $15 \%$ of clove, cinnamon and ginger, 1 and $3 \%$ chitosan, the fungicide Prochloraz at $100 \mu \mathrm{g} \cdot \mathrm{mL}^{-1}$, and a control (no treatment). The concentrations established for the extracts were based on the results of previous tests.

Ginger rhizome, cinnamon bark, and clove bud were used to prepare the aqueous extracts. Thirty grams of plant material were ground in $120 \mathrm{~mL}$ of distilled water for $1 \mathrm{~min}$. After grinding, the material was filtered through a sieve, gauze, and cotton, conditioned in an Erlenmeyer flask, and kept in a water bath at $65^{\circ} \mathrm{C}$ for $60 \mathrm{~min}$ to decontaminate. From this solution, the necessary volume was subsequently removed to obtain a concentration of 5 and $15 \%$ of the plant extract in the PDA culture medium.

One and three percent chitosan solutions were prepared and autoclaved at 15 psi for $15 \mathrm{~min}$, per HERNÁNDEZ et al. (2011).

The extract, chitosan, and fungicide solutions were added to the PDA culture media, to obtain the predetermined concentrations. After homogenization of the media, they were poured into previously identified Petri dishes, where, after solidification, $0.5 \mathrm{~cm}$ of $C$. gloeosporioides mycelium discs were transferred from cultures after 12 days of incubation. Then, the Petri dishes were sealed with plastic film and incubated in a $\mathrm{BOD}$ incubator at $25^{\circ} \mathrm{C}$, with a $12 \mathrm{~h}$ photoperiod. 
The evaluations were performed every two days for eight days; we measured mycelial diameter growth in two directions, perpendicularly, with a graduated ruler graduated in millimeters ( $\mathrm{mm}$ ).

At the end of the evaluation of mycelial growth, sporulation of $C$. gloeosporioides was also evaluated. For each repetition, a suspension of conidia was prepared by placing $10 \mathrm{~mL}$ of sterile distilled water plus Tween $20\left(0.1 \mathrm{~mL} \cdot \mathrm{mL}^{-1}\right)$ on the surface of the Petri dish with fungal mycelium, smoothly scraping it with Drigalsky's handle. The suspension was filtered through a double layer of sterile gauze to count conidia in a hemocytometer.

The mycelial growth and sporulation data were submitted to analysis of variance. The average values, when significant, were compared by Tukey's test and the average of the evaluation periods for mycelial growth was adjusted by the regression analysis, at $5 \%$ level of significance.

\section{Sensitivity of $C$. gloeosporioides conidia to natural products and a fungicide}

For the evaluation of inhibition of spore germination, a completely randomized design was used, with six treatments and five replications. The treatments were $7.5 \%$ aqueous extract of clove, cinnamon and ginger, $1.5 \%$ chitosan, the fungicide Prochloraz at $50 \mu \mathrm{g} \cdot \mathrm{mL}^{-1}$, and control (sterilized distilled water).

After 12 days of propagation, the suspension of conidia in the culture was adjusted to $1.4 \times 10^{5}$ conidia. $\mathrm{mL}^{-1}$, using a hemocytometer. The spore germination test followed the methodology described by TAVARES; SOUZA (2005).

The conidia germination data were submitted to analysis of variance, and, when significance was found, the averages were compared by Tukey's test at $5 \%$ level of significance.

\section{Effect of natural products and fungicide on the control of C. gloeosporioides during post-harvest of "Formosa" papaya "Tainung 1 "}

\footnotetext{
"Formosa" papaya "Tainung 1" from a traditional growing area, in the municipality of Ivinhema, Mato Grosso do Sul, were harvested in May 2014. We selected fruits at stage 2 of ripeness (up to $25 \%$ yellow surface), per COSTA et al. (2010).

After being harvested, the fruits were wrapped in newspaper and packed in plastic boxes, and then transported to the Laboratory of Agricultural Microbiology and Phytopathology at UFGD, in Dourados, Mato Grosso do Sul, where they were classified. We discarded those with lesions or inadequate coloration, to standardize maturation stage and fruit quality. The fruits were washed with water and detergent, and kept at room temperature until reaching $50 \%$ yellow surface; then, they were submitted to the treatments.
}

The fruits were immersed in sterilized distilled water (control), aqueous extracts (clove, cinnamon, and ginger) at $15 \%$ concentration and $8 \%$ chitosan for $5 \mathrm{~min}$, while immersion in the fungicide Prochloraz, at a concentration of $33.75 \mathrm{~g}$ a.i./100 L, was carried out for $2 \mathrm{~min}$. In both cases, drying occurred naturally.

The plant extract solutions were prepared using the methodology described in the in vitro experiment for mycelial sensitivity of $C$. gloeosporioides. The $8 \%$ chitosan solution was prepared by dissolving $800 \mathrm{~g}$ of chitosan in 10,000 mL of distilled water, then heating at $100^{\circ} \mathrm{C}$ with constant stirring for $5 \mathrm{~h}$. During the preparation, the solution was adjusted and maintained at $\mathrm{pH} 5.5$ by the addition of acetic acid P.A.

After the treatments, the fruits were packed in polystyrene cups with the stem region facing upwards, inoculated with C. gloeosporioides, per NERY-SILVA et al. (2007), and stored in a temperature-controlled chamber at $25^{\circ} \mathrm{C}$ with a $12 \mathrm{~h}$ photoperiod.

The evaluations were performed after 2, 4, and 6 days of inoculation, and scores were given based on the severity of stem-end-rot symptoms, as suggested by NERY-SILVA et al. (2007):

1. no symptoms of stem-end-rot;

2. presence of small superficial aqueous punctures (up to $3 \mathrm{~mm}$ ) in the stem region;

3. presence of aqueous or mummified lesions, not coalescing, covering a larger area around the stem;

4. presence of coalescing lesions, with translucent or mummified appearance, limited to the stem region; and

5. lesions similar to those described in scale 4, including greater extension in the fruit pulp, reaching the seed cavity, the tissue of this region may present a loss in consistency.

A completely randomized design was used, in a $6 \times 3$ factorial design, with six treatments and three evaluation periods (2, 4, and 6 days), with four replicates per treatment. The data were submitted to analysis of variance and, when significance was found, the averages between the treatments were compared by Tukey's test at $5 \%$ level of significance.

\section{RESULTS AND DISCUSSION}

\section{Mycelial sensitivity and sporulation of $C$. gloeosporioides in response to natural products and a fungicide}

Mycelial growth was completely inhibited by treatments with 5 and $15 \%$ clove, 1 and $3 \%$ chitosan, and the fungicide Prochloraz, which differed from the other treatments (Fig. 1). In the treatments in which mycelial growth occurred, the highest averages were obtained in the control, $5 \%$ ginger, and $5 \%$ cinnamon; no significant difference was observed during the evaluation period. However, at the $15 \%$ concentration, 
the two extracts resulted in lower mycelial growth. The effect of $15 \%$ ginger on mycelial growth was significantly greater than the treatment with $15 \%$ cinnamon from the first evaluation.

Inhibition of mycelial growth by ginger extract was also confirmed by BRITO; NASCIMENTO (2015): they found that the $5 \%$ concentration of ginger extract provided $70 \%$ inhibition of mycelial growth of Curvularia eragrostidis. According to DIEMER (2016), it was not possible to relate the antimicrobial activity of ginger only to the amounts found for the
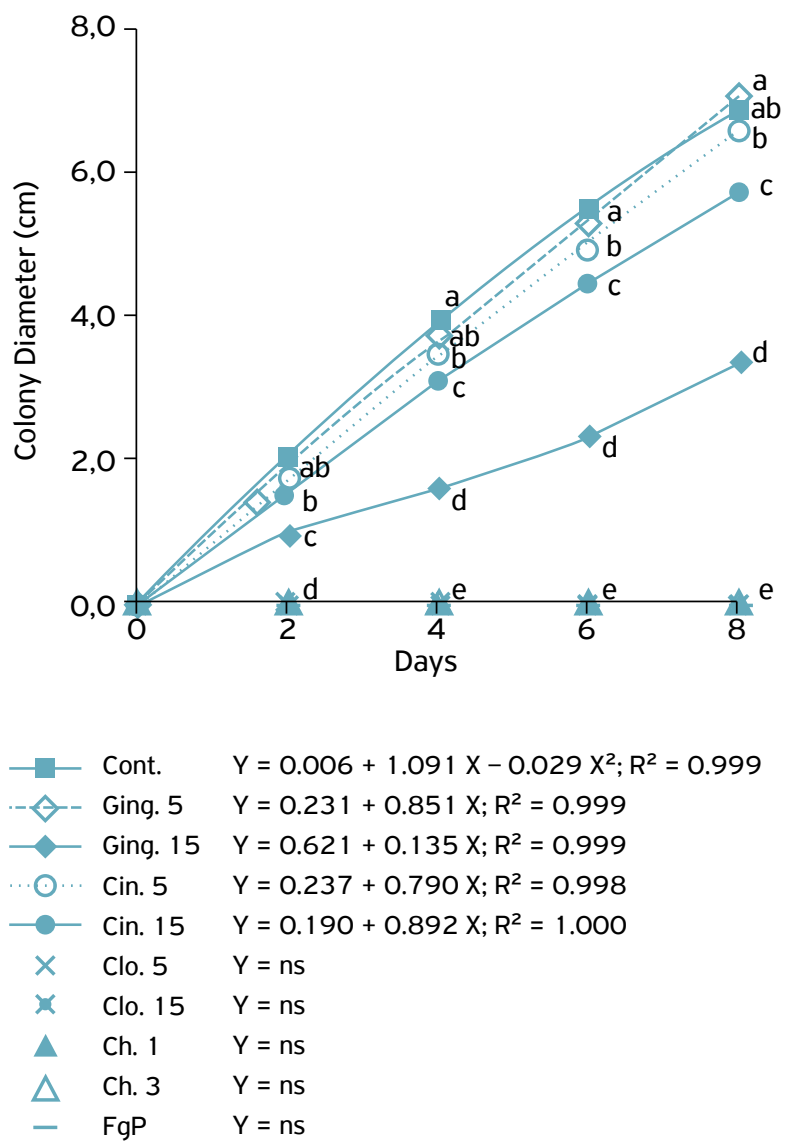

Figure 1. Mycelial growth $(\mathrm{cm})$ of Colletotrichum gloeosporioides under the effect of treatments: control (Cont.); $5 \%$ ginger (Ging. 5); 15\% ginger (Ging. 15); 5\% cinnamon (Cin. 5); $15 \%$ cinnamon (Cin. 15); $5 \%$ clove (Clo. 5); $15 \%$ clove (Clo. 15); 1\% Chitosan (Ch. 1); 3\% Chitosan (Ch. 3) and fungicide Prochloraz (FgP). Dourados, Mato Grosso do Sul, UFGD, 2014. major constituents ( $\alpha$-zingiberene, geranial, $\beta$-bisabolene, neral, and $\beta$-sesquiphellandrene). Therefore, these may be related to the synergistic effect between the constituents.

Inhibition of mycelial growth by cinnamon extract was also observed by VENTUROSO et al. (2011). They found higher antifungal activity in the highest concentrations of cinnamon aqueous extract (10 and 20\%), in vitro, without total inhibition on the phytopathogenic fungi studied, including Colletotrichum spp. The antimicrobial action of cinnamon extract is related to cinnamaldehyde, its main component (BERALDO et al., 2013).

The results obtained with the Prochloraz treatment concur with those obtained by TAVARES; SOUZA (2005). These authors also verified, in vitro, 100\% inhibition of mycelial growth of C. gloeosporioides, with $10 \mu \mathrm{g} . \mathrm{mL}^{-1}$ of Prochloraz, Propiconazole, and Tebuconazole.

The effectiveness of in vitro mycelial growth inhibition by clove extract and chitosan resembled the fungicide, demonstrating them to be promising alternatives for the control of phytopathogenic fungi. According to SILVA et al. (2009), the effective antimicrobial action of clove extract is related to the presence of eugenol (83.6\%), its main constituent. However, regarding chitosan, according to MAIA et al. (2010) and FREDDO (2012), the control efficacy is not only a function of concentration and pathogen but also of factors such as degree of deacetylation, molecular weight, $\mathrm{pH}$, and temperature.

Although sporulation did not occur in treatments with 5 and $15 \%$ clove, 1 and $3 \%$ chitosan, and the fungicide Prochloraz, it did not differ from the 15\% cinnamon and control treatments (Table 1).

The occurrence of higher production of conidia with the highest concentration of ginger was also found by RODRIGUES et al. (2006). The in vitro study conducted by this author showed that under an aqueous extract of ginger there was greater Helminthosporium spp. conidia production at concentrations of 20 and $40 \%$, compared to those of 1, 5, and $10 \%$.

Greater inhibition of sporulation with $15 \%$ cinnamon, compared to $5 \%$, suggests the possibility of complete inhibition with a higher concentration. However, according to ARAUJO et al. (2009), the control effectiveness of an extract does not only vary by its concentration but also by the species of fungus to be controlled. This was observed with the

Table 1. Sporulation, expressed by the number of $C$. gloeosporioides conidia ( $\times 10^{4}$ conidia.mL $\left.{ }^{-1}\right)$ under different treatments: control (Cont.); 5\% ginger (Ging. 5); 15\% ginger (Ging.15); 5\% cinnamon (Cin. 5); 15\% cinnamon (Cin. 15); 5\% clove (Clo. 5); 15\% clove (Clo. 15); $1 \%$ chitosan (Ch. 1); 3\% chitosan (Ch. 3), and fungicide Prochloraz at $100 \mu \mathrm{g} . \mathrm{mL}^{-1}$ (FgP). Dourados, Mato Grosso do Sul, UFGD, 2014.

\begin{tabular}{|c|c|c|c|c|c|c|c|c|c|}
\hline \multicolumn{10}{|c|}{ Treatments } \\
\hline Cont. & Ging. 5 & Ging. 15 & Cin. 5 & Cin. 15 & Clo. 5 & Clo. 15 & Ch. 1 & Ch. 3 & FgP \\
\hline $26.8 b^{*}$ & $69.1 \mathrm{ab}$ & $185.2 \mathrm{a}$ & 195.0a & $17.5 b$ & $0.0 b$ & $0.0 b$ & $0.0 b$ & $0.0 b$ & $\mathrm{O} . \mathrm{Ob}$ \\
\hline CV\%: $98.31 \mathrm{c}$ & & & & & & & & & \\
\hline
\end{tabular}

*Averages transformed second root $(x+0.5)$. Averages followed by the same letter in line do not differ statistically from each other by the $F$-test and Tukey's test at $5 \%$ level of significance; CV: coefficient of variation. 
aqueous extract of $10 \%$ cinnamon, which inhibited the sporulation of Penicillium roqueforti, but had no effect on the production of Aspergillus ochraceus spores.

The results obtained with the clove extract are equivalent to those obtained with the fungicide, showing it to be a promising alternative in the control of phytopathogenic fungi. LORENZETTI et al. (2011), when evaluating the effect of clove essential oil on Botrytis cinerea, found that, although this pathogen had presented mycelial growth, it did not produce spores during the evaluation. This result supports disease control, due to increasing the time required for reproduction. These authors attributed the fungistatic and fungicidal effect to the presence of eugenol, which is the major component of clove.

The inhibition of sporulation by chitosan was also observed by BARRETO (2016). It was verified that the incorporation of chitosan at $4 \mathrm{mg} \cdot \mathrm{mL}^{-1}$ in culture media with Aspergillus niger and Rhizopus stolonifer inhibited sporulation of both to less than $50 \%$, which differed from the control. However, the association of chitosan and oregano oil (Origanum vulgare L.) provided 100\% inhibition of sporulation. Similar results were also obtained for spore germination and mycelial growth. SILVA et al. (2015) found that the in vivo use of $2 \%$ chitosan reduced the spore concentration and the production of Aspergillus parasiticus in peanuts, and promoted, in vitro, morphological changes in the spores, such as swelling, larger diameter $(20 \mu \mathrm{m})$, and absence of spicules. According to COQUEIRO; DI PIERO (2011), the exact mechanism of action on the pathogen is not yet fully understood. However, it is believed that its cationic nature contributes to the performance of chitosan, since its positive charges can interact with the negatively charged residues of macromolecules exposed on the surface of the pathogen cell, altering cell membrane permeability.

\section{Sensitivity of $C$. gloeosporioides conidia to natural products and a fungicide}

The germination of C. gloeosporioides spores presented high sensitivity to treatments with $1.5 \%$ chitosan, $7.5 \%$ clove, and the fungicide Prochloraz; these treatments presented significantly lower average values than the other treatments. The germination of conidia exposed to $7.5 \%$ cinnamon extract was significantly lower than in the control (Table 2).

The result obtained with $1.5 \%$ chitosan was also found by MAIA et al. (2010). They found that treatment with $160 \mathrm{mg} \cdot \mathrm{L}^{-1}$ of chitosan reduced the germination of spores of Elsinoe ampelina by $98 \%, 12$ and $24 \mathrm{~h}$ after incubation. Inhibition of spore germ tubes by chitosan is related to the modification of plasma membrane permeability, making it difficult for nutrients to enter the cells (DI PIERO; GARDA, 2008).

The sensitivity observed with the $7.5 \%$ clove treatment was also shown by LUCAS (2012), who observed complete inhibition of Alternaria solani conidia germination, under the effect of clove essential oil in vitro. CELOTO et al. (2008) found that aqueous extracts provided a greater percentage of inhibition of $C$. gloeosporioides spore germination, in relation to hydroethanolic extracts.

The inhibition verified with $7.5 \%$ aqueous cinnamon extract was also found by MAMPRIM et al. (2013) with M. anisopliae. When spraying aqueous extract of $10 \%$ cinnamon on the fungus that was previously inoculated in PDA culture medium, they verified that conidia germination was reduced by $24 \%$. LIMA et al. (2012) observed that with the increase in cinnamon aqueous extract concentration (10, 25, 50, and 100\%), there was a reduction in Aspergillus flavus spore germination.

The germination of spores shown with $7.5 \%$ ginger extract was also observed by CELOTO et al. (2008), who found that the $20 \%$ aqueous extract of ginger did not inhibit C. gloeosporioides germination in vitro.

The efficacy observed in the fungicide treatment was also obtained by TAVARES; SOUZA (2005); their study showed that the fungicide Prochloraz, in the concentration of $100 \mu \mathrm{g}$. $\mathrm{mL}^{-1}$, provided $100 \%$ inhibition of the C. gloeosporioides spore germination.

\section{Effect of natural products and fungicide on the control of C. gloeosporioides in post-harvest "Formosa" papaya "Tainung 1 "}

In vivo evaluations showed no significant differences between treatments on the second day of evaluation. However, anthracnose control was verified by treatments with $15 \%$ clove, $8 \%$ chitosan, and Prochloraz on the fourth and sixth day. The treatment with $15 \%$ cinnamon presented intermediate control, differing from the control on the fourth day. The $15 \%$ ginger treatment did not differ from the control group on the fourth and sixth day of evaluation, showing the same pattern of lesion growth

Table 2. Spore germination (\%), in vitro, of C. gloeosporioides under different treatments: control (Cont.); $7.5 \%$ ginger (Ging 7.5); $7.5 \%$ cinnamon (Cin. 7.5 ); $7.5 \%$ clove (Clo. 7.5 ); $1.5 \%$ chitosan (Ch. 1.5), and the fungicide Prochloraz at $50 \mu \mathrm{g} \cdot \mathrm{mL}^{-1}$ (FgP). Dourados, Mato Grosso do Sul, UFGD, 2014.

\begin{tabular}{lc} 
Treatment* & Germination (\%) \\
\hline Cont. & $15.3 \mathrm{a}$ \\
\hline Ging. 7.5 & $12.0 \mathrm{ab}$ \\
\hline Cin. 7.5 & $7.9 \mathrm{~b}$ \\
\hline Clo. 7.5 & $0.5 \mathrm{c}$ \\
\hline Ch. 1.5 & 0.0c \\
\hline FgP & 0.0c \\
\hline CV\%: 30.796 & \\
\hline
\end{tabular}

Averages followed by the same letter in the column do not differ statistically from each other by the F-test and Tukey'stest at $5 \%$ level of significance. Treatments resulting from the final dilution $1: 1$ in distilled water and sterile; CV: coefficient of variation. 
throughout the evaluations; and the severity of the disease increased between the second and fourth day, without differing between the fourth and sixth day. However, in treatments where there was greater control of the disease, the severity increased significantly after the second evaluation (Table 3 ).

The lower efficacy of the treatment with $15 \%$ ginger extract indicates the control indexes shown in the in vitro experiments, in relation to the other treatments. However, STANGARLIN et al. (1999), verifying the elicitor effect of phytoalexins in bioassays with sorghum and soybean, found that the raw aqueous extract of ginger had the capacity to activate defense mechanisms in these plants.

Table 3. Severity of anthracnose in "Formosa" papaya "Tainung 1 ", under different treatments: control (Cont.); $15 \%$ ginger (Ging. 15); 15\% cinnamon (Cin. 15); 15\% clove (Clo. 15); 8\% chitosan (Ch. 8), and the fungicide Prochloraz 33.75 g i.a./100 L (FgP). Dourados, Mato Grosso do Sul, UFGD, 2014.

\begin{tabular}{lccc} 
Treatment & \multicolumn{3}{c}{ Severity } \\
\cline { 2 - 4 } & Second day & Fourth day & Sixth day \\
Cont. & $1.0 \mathrm{aB}$ & $3.5 \mathrm{aA}$ & $4.0 \mathrm{aA}$ \\
\hline Ging. 15 & $1.0 \mathrm{aB}$ & $3.5 \mathrm{aA}$ & $3.7 \mathrm{abA}$ \\
\hline Cin. 15 & $1.0 \mathrm{aC}$ & $2.5 \mathrm{bB}$ & $3.2 \mathrm{abA}$ \\
\hline Clo. 15 & $1.0 \mathrm{aB}$ & $1.5 \mathrm{cB}$ & $3.0 \mathrm{bA}$ \\
\hline Ch. 8 & $1.0 \mathrm{aB}$ & $1.5 \mathrm{cB}$ & $3.0 \mathrm{bA}$ \\
\hline FgP & $1.0 \mathrm{aB}$ & $1.5 \mathrm{cB}$ & $3.0 \mathrm{bA}$ \\
\hline CV\%: 16.77 & & & \\
\hline
\end{tabular}

Averages followed by the same letter, lowercase in the column and upper case in the row, do not differ statistically from each other by the F-test and Tukey's test at $5 \%$ level of significance; CV: coefficient of variation. Level of disease severity by a score scale of $O$ to $5:(1)$ absence of symptoms of stem-end-rot; (2) presence of small superficial aqueous punctures (up to $3 \mathrm{~mm}$ ) in the peduncle region; (3) presence of aqueous or mummified lesions, not coalescing, covering a larger area around the stem; (4) presence of coalescing lesions, with translucent or mummified appearance, limited to the stem region; and (5) lesions similar to those described in scale 4, including greater extension in the fruit pulp, reaching the seed cavity, the tissue of this region may present a loss in consistency.
The intermediate control obtained with the $15 \%$ cinnamon extract indicates the possibility of obtaining a better result with a higher concentration. In the literature, no studies evaluating the phytopathogenicity of cinnamon aqueous extract were found in vivo, but only in vitro. However, there are in vivo studies with cinnamon essential oil that have demonstrated its antimicrobial action. ANDRADE; VIEIRA (2016) observed that the low efficacy of the cinnamon essential oil in the post-harvest control of C. gloeosporioides in "Golden" papaya was due to low dosage $(100 \mu \mathrm{L})$, since there was gradual inhibition of this fungus with increased concentrations.

The inhibition of the growth of $C$. gloeosporioides lesions found in the $8 \%$ chitosan treatment is related, according to MAIA et al. (2010), to the fungistatic effect of chitosan and its potential to activate enzymes and phenolic compounds related to the plant defense mechanism.

Although our study demonstrated anthracnose control with the $15 \%$ clove treatment, there are no studies that demonstrate the in vivo behavior of clove in the control of phytopathogens. However, in vitro studies by COSTA et al. (2011) and LUCAS (2012) show that eugenol and $\beta$-caryophyllene act on the degradation of the cell wall, with morphological changes in fungal mycelium, disorganization of cellular contents, intense fragmentation, and less turgidity of the hyphae.

\section{CONCLUSION}

The aqueous extracts of cinnamon and ginger showed potential inhibition of C. gloeosporioides development in vitro. However, in vivo, the anthracnose control effectiveness of the $15 \%$ doses was low.

Chitosan and aqueous clove extract are effective in inhibiting mycelial growth, and production and germination of $C$.gloeosporioides conidia in vitro, as well as in reducing the severity of anthracnose in vivo. They present a viable alternative to Prochloraz fungicide for post-harvest protection of "Formosa" papaya.

| | | | | | | | | | | | | | | | | | | | | | | | | | | | | | | | | | | | | | | | | | | | | | | | | | | | | | | | | | | | | | | | | | | | | | | | | | | | | | | | | | | | | | | | | | | | | | | | | | | | | | | | | | | | | | | | | | | | | | | | | | | | | | | | | | | | | | | | | | | | | | | | | | | | | | | | | | | | | | | | | | | | | | | | | | | | | | | | | | | | | | | | | | | | | | | | | | | | | | | | | | | | | | | | | | | | | | | | | | | | |

\section{REFERENCES}

ANDRADE, W.P.; VIEIRA, G.H.C. Efeito dos óleos essenciais sobre a antracnose in vitro e em frutos de mamoeiro. Revista Brasileira de Plantas Medicinais, Campinas, v.18, n.1, suppl.1, p.367372, 2016. Available from: <http://www.scielo.br/pdf/rbpm/ v18n1s1/1516-0572-rbpm-18-1-s1-0367.pdf>. Access on: 18 May 2016. http://dx.doi.org/10.1590/1983-084X/15_089

AGÊNCIA NACIONAL DE VIGILÂNCIA SANITÁRIA (ANVISA). Resolução RDC n.60, de 3 de fevereiro de 2016. Dispõe sobre a proibição da utilização do ingrediente ativo procloraz em produtos agrotóxicos, em decorrência de sua reav. toxicológica. Diário
Oficial da União, Brasília, 4 fev., 2016. Available from: <http:// pesquisa.in.gov.br/imprensa/jsp/visualiza/index.jsp?jornal $=1 \&$ pagina $=48 \&$ data $=04 / 02 / 2016>$. Access on: 18 May 2016.

ARAUJO, R.C.Z.; CHALFOUN, S.M.; ANGÉLICO, C.L.; ARAUJO, J.B.S.; PEREIRA, M.C. Avaliação in vitro da atividade fungitóxica de extratos de condimentos na inibição de fungos isolados de pães artesanais. Ciência e Agrotecnologia, Lavras, v.33, n.2, p. 545-551, 2009. Available from: <http://www.scielo.br/pdf/cagro/v33n2/v33n2a29.pdf>. Access on: 1 Dec. 2017. 
BARRETO, T.A Efeitos da aplicação de revestimento de quitosana e óleo essencial de orégano no controle da qualidade pós-colheita em tomates cereja. 2016. 88f. Dissertação (Mestrado em Ciência e Tecnologia de Alimentos) - Universidade Federal da Paraíba, João Pessoa, 2016. Available from: <https://repositorio.ufpb.br/jspui/bitstream/ tede/9438/2/arquivototal.pdf >. Access on: 27 Nov. 2017.

BERALDO, C.; DANELUZZI, N.S.; SCANAVACCA, J.; DOYAMA, J.T.; FERNANDES JÚNIOR, A.; MORITZ, C.M.F. Eficiência de óleos essenciais de canela e cravo-da-índia como sanitizantes na indústria de alimentos. Pesquisa Agropecuária Tropical, Goiânia, v.43, n.4, p.436-440, 2013. Available from: <http://www. scielo.br/pdf/pat/v43n4/06.pdf>. Access on: 27 Nov. 2017.

BONILLA, J.; SOBRAL, P.J.A. Antioxidant and antimicrobial properties of ethanolic extracts of guarana, boldo, rosemary and cinnamon. Brazilian Journal of Food Technology, Campinas, v.20, e2016024, 2017. Available from: <http://www.scielo.br/ $\mathrm{pdf} / \mathrm{bjft} / \mathrm{v} 20 / 1981-6723-\mathrm{bjft}-20-e 2016024 . \mathrm{pdf}>$. Access on: 27 Nov. 2017. http://dx.doi.org/10.1590/1981-6723.2416

BRITO, N.M.; NASCIMENTO, L.C. Potencial fungitóxico de extratos vegetais sobre Curvularia eragrostidis (P. Henn.) Meyer in vitro. Revista Brasileira de Plantas Medicinais, Paulínia, v. 17, n.2, p.230238, 2015. Available from: <http://www.scielo.br/pdf/rbpm/ v17n2/1516-0572-rbpm-17-2-0230.pdf >. Access on:27 Nov. 2017. http://dx.doi.org/10.1590/1983-084X/10_057

CARNELOSSI, P.R.; SCHWAN-ESTRADA, K.R.F.; CRUZ, M.E.S.; ITAKO, A.T.; MESQUINI, R.M. Óleos essenciais no controle póscolheita de Colletotrichum gloeosporioides em mamão. Revista Brasileira de Plantas Medicinais, Botucatu, v. 1 1, n.4, p.399406, 2009. Available from: <http://www.scielo.br/pdf/rbpm/ v1 1n4/aO7v1 1n4.pdf>. Access on: 27 Nov. 2017. http://dx.doi. org/10.1590/S1516-05722009000400007

CELOTO, M.I.B.; PAPA, M.F.S.; SACRAMENTO, L.V.S.; CELOTO, F.J. Atividade antifúngica de extratos de plantas a Colletotrichum gloeosporioides. Acta Scientiarum Agronomy, Maringá, v.30, n.1, p. 1-5, 2008. Available from: <http://www.scielo.br/pdf/asagr/ v30n 1/v30n1aO1.pdf>. Access on: 27 Nov. 2017 . http:// dx.doi.org/10.4025/actasciagron.v30i 1.1104

CIA, P.; BENATO, E.A.; PASCHOLATI, S.F.; GARCIA, E.O. Quitosana no controle pós-colheita da podridão mole em caqui 'Rama Forte'. Bragantia, Campinas, v.69, n.3, p.745-752, 2010. Available from: <http://www.scielo.br/pdf/brag/v69n3/28. pdf>. Access on: 27 Nov. 2017. http://dx.doi.org/10.1590/ S0006-87052010000300028

COQUEIRO, D.S.O.; DI PIERO, R.M. Atividade de quitosanas com diferentes pesos moleculares sobre alternaria solani. Arquivos do Instituto Biológico, v.78, p.459-463, 2011 . Available from: <http://www.biologico.sp.gov.br/uploads/docs/arq/v78_3/ coqueiro.pdf $>$. Access on: 27 Nov. 2017.

COSTA, A.R.T.; AMARAL, M.F.Z.J.; MARTINS, P.M.; PAULA, J.A.M.; FIUZA, T.S.; TRESVENZOL, L.M.F.; PAULA, J.R.; BARA, M.T.F. Ação do óleo essencial de Syzygium aromaticum (L.) Merr. \& L. M. Perry sobre as hifas de alguns fungos fitopatogênicos. Revista Brasileira de Plantas Medicinais, Paulínia, v.13, n.2, p.240-245, 2011. Available from: <http://www.scielo.br/pdf/rbpm/v13n2/ v13n2a 18.pdf>. Access on: 27 Nov. 2017. http://dx.doi. org/10.1590/S1516-05722011000200018
COSTA, F.B.; MENEZES, J.B.; ALVES, R.E.; NUNES, G.H.S.; MARACAJÁ, PB. Armazenamento refrigerado do mamão Havaí "Golden" produzido na chapada do Apodi - RN - Brasil. Revista Verde, Mossoró, v.5, n.4, p.37-54, 2010. Available from: <https:// www.alice.cnptia.embrapa.br/alice/bitstream/doc/876244/1/ PG 10006.pdf>. Access on: 27 Nov. 2017.

DIEMER, AW. Ação antimicrobiana de Rosmarinusofficinalis e Zingiber officinale frente à Escherichia coli e Staphylococcus aureus em carne mecanicamente separada de frango. 2016.69f. Dissertação (Mestrado em Biotecnologia) - Centro Universitário UNIVATES, Lajeado, 2016. Available from: <https://www.univates. br/bdu/bitstream/10737/1075/1/2016AndreaWolfDiemer. pdf >. Access on: 27 Nov. 2017.

DI PIERO, R.M.; GARDA, M.V. Quitosana reduz a severidade da antracnose e aumenta a atividade de glucanase em feijoeirocomum. Pesquisa Agropecuária, Brasília, v.43, n.9, p.11211128,2008 . Available from: <http://www.scielo.br/pdf/pab/ v43n9/04.pdf>. Access on: 27 Nov. 2017.

FONTANA, D.C.; KULCZYNSKI, S.M.; TREVISAN, R.; SCHMIDT, D.; CARON, B.O.; PINHEIRO, M.V.M.; PRETTO, M.M.; DIEL, M.I. Uso de extratos vegetais no controle alternativo da podridão parda do pessegueiro. Revista Cultivando o Saber, Cascavel, v.10, n.2, p.148-165, 2017. Available from: <https://www.fag.edu.br/upload/revista/cultivando_o_ saber/59a5b4143085c.pdf>. Access on: 27 Nov. 2017.

FREDDO, A.R. Quitosana in vitro e no tratamento de sementes de eucalipto e acácia-negra no controle de Rhizoctoniasolani e no desenvolvimento inicial das plântulas. 2012. 78f. Dissertação (Mestrado em Agronomia) - Universidade Tecnológica Federal do Paraná, Pato Branco, 2012. Available from: <http://repositorio. utfpr.edu.br/jspui/handle/1/276>. Access on: 27 Nov. 2017.

HERNÁNDEZ, A.M.A.; NECHA, L.L.B.; LAUZARDO, A.N.H.; DEL VALLE, M.G.V. Actividad antifúngica del quitosano y aceites esenciales sobre Rhizopus stolonifer (Ehrenb.:Fr.) Vuill., agente causal de la pudrición blanda del tomate. Revista Colombiana de Biotecnologia, Bogotá, v.13, n.2, p.127-134, 2011 . Available from: <http://www.scielo.org.co/pdf/biote/v13n2/v13n2a 11. pdf >. Access on: 27 Nov. 2017.

LIMA, C.Q.; ALMEIDA, F.A.C.; ARAÚJO, E.; SILVA, J.F.; MORAES, A.M.; MEDEIROS, D.S. Bioatividade de extratos e óleos vegetais no controle in vitro de Aspergillus flavus em sementes de amendoim. Tecnologia \& Ciência Agropecuária, João Pessoa, v.6, n. 1, p.1318, 2012. Available from: <http://revistatca.pb.gov.br/edicoes/ volume-06-2012/volume-6-numero-1-marco-2012/tca6103. pdf >. Access on: 27 Nov. 2017.

LORENZETTI, E.R.; MONTEIRO, F.P.; SOUZA, P.E.; SOUZA, R.J.; SCALICE, H.K.; DIOGO JUNIOR, R.; PIRES, M.S.O. Bioatividade de óleos essenciais no controle de Botrytiscinerea isolado de morangueiro. Revista Brasileira de Plantas Medicinais, Botucatu, v.13, n.especial, p.619-627, 2011. Available from: <http://www.scielo.br/pdf/ rbpm/v13nspe/a19v13nspe.pdf>. Access on: 27 Nov. 2017.

LUCAS, G.C. Óleos essenciais no controle da pinta preta do tomateiro. 2012. 92f. Tese (Doutorado em Fitopatologia) - Universidade Federal de Lavras, Lavras, 2012. Available from: <http:// repositorio.ufla.br/bitstream/1/906/1/TESE_\%C3\%93leos\%20 essenciais\%20no\%20controle\%20da\%20pinta\%20preta\%20 do\%20tomateiro.pdf>. Access on: 27 Nov. 2017. 
MAIA, A.J.; BOTELHO, R.V.; FARIA, C.M.D.R.; LEITE, C.D. Ação de quitosana sobre o desenvolvimento de Plasmoporaviticola e Elsioneampelina, in vitro e em videiras cv. 'Isabel'. Summa Phytopathologica, Botucatu, v.36, n.3, p.203-209, 2010. Available from: <http://www.scielo.br/pdf/ sp/v36n3/v36n3a03.pdf>. Access on: 27 Nov. 2017. doi: $10.1590 /$ SO $100-54052010000300003$

MAMPRIM, A.P.; ALVES, L.F.A.; PINTO, F.G.S.; FORMENTINI, M.A.; MARTINS, C.C.; BONINI, A.K. Efeito de defensivos agrícolas naturais e extratos vegetais sobre parâmetros biológicos de Metarhizium anisopliae (Metsch.) Sorok. Semina, Londrina, v.34, n.4, p.1451-1466, 2013. Available from: <http://www.redalyc. org/html/4457/445744122002/>. Access on: 27 Nov. 2017. DOI: $10.5433 / 1679-0359.2013 v 34 n 4 p 1451$

NERY-SILVA, F.A.; MACHADO, J.C.; RESENDE, M.L.V.; LIMA, L.C.O. Metodologia de inoculação de fungos causadores da Podridão peduncular em mamão. Ciência e Agrotecnologia, Lavras, v.31, n.5, p.1374-1379, 2007. Available from: <http://www.scielo. br/pdf/cagro/v31n5/15.pdf>. Access on: 27 Nov. 2017.

RODRIGUES, E.; SCHWAN-ESTRADA, K.R.F.; STANGARLIN, J.R.; CRUZ, M.E.S; TUTIDA-FIORI, A.C.G. Avaliação da atividade antifúngica de extratos de gengibre e eucalipto in vitro e em fibras de bananeira infectadas com Helminthosporium sp. Acta Scientiarum Agronomy, Maringá, v.28, n.1, p.123-127, 2006. Available from: <http://www.redalyc.org/pdf/3030/303026568006. pdf>. Access on: 27 Nov. 2017.

SCHWAN-ESTRADA, K.R.F. Extratos vegetais e de cogumelos no controle de doenças de plantas. Horticultura Brasileira, Brasília, v.27, n.2, S4038-S4045, 2009. Available from: <http://www. abhorticultura.com.br/eventosx/trabalhos/ev_3/MR_4_Artigo_ Katia_Regina_Estrada.pdf>. Access on: 27 Nov. 2017.

SILVA, A.C.; SALES, N.L.P.; ARAÚJO, A.V.; CALDEIRA JUNIOR, C.F. Efeito in vitro de compostos de plantas sobre o fungo Colletotrichum gloeosporioides penz. Isolado do maracujazeiro. Ciência e Agrotecnologia, Lavras, v.33, Edição Especial, p. 18531860, 2009. Available from: <http://www.scielo.br/pdf/cagro/ v33nspe/26.pdf>. Access on: 27 Nov. 2017.

SILVA, J.F.M.; PRADO, G.; MADEIRA, J.E.G.C.; OLIVEIRA, M.S.; FARACO, A.A.G.; MALTA, C.M.; NICOLI, J.R.; PIMENTA, R.S. Utilização de filme de quitosana para o controle de aflatoxinas em amendoim. Bragantia, Campinas, v.74, n.4, p.467-475, 2015. Available from: <http://www.scielo.br/pdf/brag/v74n4/00068705-brag-1678-44990120.pdf>. Access on:27 Nov. 2017. http://dx.doi.org/10.1590/1678-4499.0120

SIQUEIRA JUNIOR, C.L.; MORAES, T.C.; MARTINS, J.A.B.; FREIRE, M.G.M. Controle de antracnose em mamão por extratos vegetais. Biológicas \& Saúde, v.1, n.1, p.99-105, 2011 . Available from: <http://www.seer.perspectivasonline.com.br/index.php/ biologicas_e_saude/article/viewFile/517/429>. Access on: 27 Nov. 2017. DOI: https://doi.org/10.25242/8868112011517

STANGARLIN, J.R.; SCHWAN-ESTRADA, K.R.F.; CRUZ, M.E.S.; NOZAKI, M.H. Plantas medicinais e o controle alternativo de doenças de plantas. Biotecnologia Ciência @ Desenvolvimento, Brasília, v. 11, p.16-21, 1999.

TARNOWSKI, T.L.B. Using molecular analysis to investigate phylogenetic relationships in two tropical pathosystems: witches' broom of cacao, caused by Moniliophthora perniciosa, and mango anthracnose, caused by Colletotrichum spp. 2009. 236 p. Thesis (Doctorate in Philosophy) $\otimes$ University of Florida, Gainesville, 2009. Available from: <http://etd.fcla.edu/UF/UFE0041003/ tarnowski_t.pdf $>$. Access on:26 Apr. 2018.

TAVARES, G.M.; SOUZA, P.E. Efeito de fungicidas no controle in vitro de Colletotrichum gloeosporioides, agente etiológico da antracnose do mamoeiro (Caricapapaya L.). Ciência e Agrotecnologia, Lavras, v.29, n.1, p.52-59, 2005. Available from: <http://www.scielo. br/pdf/cagro/v29n1/a06.pdf>. Access on: 27 Nov. 2017. http://dx.doi.org/10.1590/S1413-70542005000100006

TORRES-CALZADA, C.; TAPIA-TUSSELL, R.; HIGUERA-CIAPARA, I.; PEREZ-BRITO, D. Morphological, pathological and genetic diversity of Colletotrichum species responsible for anthracnose in papaya (Carica papaya L). European Journal of Plant Pathology, Sochi, v.135, n.1, p.67-79, 2012. Available from: <https:// www.researchgate.net/publication/257558376>. Access on: 26 Apr. 2018. DOI: 10.1007/s10658-012-0065-7

VENTUROSO, L.R.; BACCHI, L.M.A.; GAVASSONI, W.L.; CONUS, L.A.; PONTIM, B.C.A.; SOUZA, F.R. Inibição do crescimento in vitro de fitopatógenos sob diferentes concentrações de extratos de plantas medicinais. Arquivos do Instituto Biológico, São Paulo, v.78, n. 1, p.89-95, 2011 . Available from: <http://www.biologico.sp.gov.br/ uploads/docs/arq/v78_1/venturoso.pdf>. Access on: 27 Nov. 2017. 